\title{
Hong Kong: The Crack-up
}

Frank S. Hong

You cannot think without abstractions; accordingly, it is of the utmost importance to be vigilant in critically revising your modes of abstraction ... A civilization which cannot burst through its current abstractions is doomed to sterility after a very limited period of progress.

Alfred North Whitehead ${ }^{1}$

\begin{abstract}
Hong Kong is typically celebrated as the Oriental Pearl owing its prosperity to a free economy and the British rule of law, and lately the frontline of a pro-democracy movement that courageously confronts the authoritarian sovereign to its north. In reality, Hong Kong, as ominously foretold by its geographic features, has been cracking up like a plate. This metaphor is more of a methodological insight than a mere rhetoric device in that it takes nothing short of a rigorous analysis at the micro level to overcome the deeply entrenched bending of the nearly two-century long arc of Hong Kong's life for geopolitical and propaganda purposes at various junctures. This Essay is an exercise of critical phenomenology that seeks to challenge the grand myth of Hong Kong's autonomy and expose the lines of flight that have caused unrests in Hong Kong and fissures in America alike.
\end{abstract}

$* * *$

Time

"Capitalists (factory owners and house-owners) want quick returns - money back in 5 years, not 20 - for fear something happens before. No one knows how long Hong Kong will exist, or how long it will prosper. One has to make allowances for this." -- Except from report by Sheila Ann Ogilvie, Assistant Labour Officer, Colonial Office in $1958 .^{2}$

The first and second world wars were 22 years apart. The longest war by the U. S. lasted 19 years in Afghanistan.

The Bretton Woods System lasted 27 years. The Brexit took place 47 years after the Great Britain joined the EU in 1973.

1 Alfred North Whitehead, Science and the Modern World, (The Free Press, 1967) at 59. (This was first published in 1925 based on the Lowell Lecture in 1925.)

2 David Faure, Colonialism and The Hong Kong Mentality, (The University of Hong Kong, 2003) at 179. 
The British force occupied the island of Hong Kong in January, 1841. By Article III of the Treaty of Nanking, Hong Kong became a colony of the Great Britain. Kowloon, the tip of mainland opposite the Hong Kong island was annexed by the British around 1860. The New Territories, a piece of land 10 times larger than the island of Hong Kong fell into the British hands around 1898. Curiously, this large piece of land was taken by Britain under a 99-year lease from China. The lease expired at midnight on June $30^{\text {th }}, 1997$. On the next day, the entire territory of Hong Kong returned to China as a special administrative region.

In today's China, the statutory term for the residential land right is 70 years, industrial land 50 years, and commercial land 40 years.

When the People's Republic of China was founded in 1949, it was the third regime in China since the lease of the New Territories. Between 1897 and 1949 there were two world wars and one bloody Chinese civil war that lasted 27 years.

When the Sino-British Joint Declaration (1984) pledged that Hong Kong's way of life would remain unchanged for 50 years, the PRC was only 35 years old.

\section{Baby Formula}

Effective on March 1st, 2013, the Import and Export (General)(Amendment) Regulation 2013 of Hong Kong prohibits "the unlicensed export of powdered formula, including milk powder and soya milk powder, for infants and children under 36 months." 3 Offenders are liable on conviction to a fine of HK\$500,000 (about US\$65,000) and to imprisonment for 2 years. This is serious. And it is also monumentally scandalous. An international free port imposes export control on baby formula! A free port that was forced open in the wake of opium trade over 100 years ago now limits export of baby formula! An international port that followed American laws to embargo against China during the Cold War, by its own volition, restricts export of baby formula, for the most part, to mainland China in the era of free trade!

The shortage of baby formula in Hong Kong, a city thriving on free flow of capital and goods, is as "inexplicable" as the homeless in America, to paraphrase Alexis de Tocqueville's observation while travelling in England in 1835: “...among the peoples most admired for their opulence, one part of the population is obligated to rely on the gifts of the other in order to live." " In Hong Kong, the crisis was not lacking affordable baby formula in the sense "affordable" housing is lacking in America. It was lacking the timely supply of baby formula. A matter of much lower magnitude. This law was duly passed by the Hong Kong legislature and strictly enforced by the Customs. The

3 https://www.customs.gov.hk/en/whats_new/API/index.html

4 Alexis de Tocqueville, Memoir on Pauperism, translated by Seymour Drescher, with an introduction by Gertrude Himmelfarb, (May 1997) 
puzzle remains as to why the shortage of baby formula occurred in Hong Kong in the first place. This did not happen in 2000s, 1990s or even earlier. The cause of the shortage did not lie in any unusual consumption pattern of the Hong Kong residents. Rather, it was the tourists/shoppers from the mainland of China who bought so much baby formula in Hong Kong that they could empty the store shelves to the annoyance of local residents. The export ban is designed to ensure that mainland tourists could only carry a limited amount of baby formula for reasonable personal use during the travel, so local residents no longer suffer from the temporary shortage on the shelves.

\section{Locusts}

Shoppers from mainland China could not be called "yellow peril" for the simple reason that Hong Kong residents are mostly Chinese by ethnicity of the same skin color. But the sentiment was similar. For each line of business that benefits from a surging demand from mainlanders, there are likely many more local residents suffering from the crowdedness or driven-up price as a result. Many mainlanders are ill-mannered when they speak loudly in public space or eat instant noodles on subway trains.

Not surprisingly, in 2012, a group of Hong Kong residents have placed an advertisement in a popular tabloid Apple Daily, calling people from mainland China "locusts". 5 The point of this offensive imagery is not what a single locust can do. Rather, the collective menace comes from locusts swarming in large numbers.

The impact of surging demand from mainland Chinese reaches beyond Hong Kong. The U. S. Postal Service is financially overwhelmed by the number of small packages sent from Chinese vendors. ${ }^{6}$ The U. S. Patent and Trademark Office was alarmed by the flood of trademark applications filed by Chinese applicants. ${ }^{7}$ In top American engineering schools or departments, students from China are typically more than one third of the class. For many cash-strapped colleges in Australia, Great Britain and America, tuition from Chinese students make up a significant portion of their budgets. In 2013, President Obama spoke in South Africa:

Ultimately, if you think about all the youth that everybody has mentioned here in Africa, if everybody is raising living standards to the point where everybody has got a car and everybody has got air conditioning, and everybody has got a big house, well, the planet will boil over -- unless we find new ways of producing energy.

5 https://www.bbc.com/news/world-asia-china-16828134

6 Wade Shepard, As U.S. Postage Rates Continue to Rise, The USPS Gives the Chinese A 'Free Ride', Forbes, Nov. 5th 2017, https://www.forbes.com/sites/wadeshepard/2017/11/05/how-theusps-epacket-gives-postal-subsidies-to-chinese-e-commerce-merchants-to-ship-to-the-usacheap/\#2c16f71940ca

7 Jacob Gershman, Flood of Trademark Applications from China Alarms U.S. Officials, the Wall Street Journal, May 5th, 2018, https://www.wsj.com/articles/flood-of-trademark-applicationsfromchinaalarms-u-s-officials- 1525521600 
The same point applies to consumers in China. Hong Kong, a special administrative region under the P. R. China, bore the impact from a growing Chinese middle class sooner and in a more dramatic manner than others did, primarily because of its physical proximity to the mainland. When shortage, proximity and bad manners mixed together, even New Yorkers felt the explosive urge to blow up the bridge: ${ }^{8}$ "It's not just the drastic food shortage out here. Every aspect of life, most crucially medical care, is under strain by the sudden influx of rich Manhattanites panic-fleeing, bringing along their disdain and disregard for the little people - and in some cases, knowingly bringing coronavirus", a Hampton local resident complained to the reporter. That fairly depicted the same kind of resentment felt by Hong Kong residents towards mainlanders who were mostly not even rich, but they need to come to see Hong Kong, the Oriental Pearl and do some shopping, typically as their very first trip "overseas". Each year Hong Kong receives about 40 million visitors from the mainland.

Unlike Hampton residents who experienced COVID-19-fleeing Manhattanites only once in a life time, Hong Kong residents deal with the influx of mainlanders on the daily basis. Hong Kong is not holding up well. The renegade on the principle of free flow of goods, while not sensational enough to make headlines, is in fact a fatal crackup, and it is a harbinger of things to come.

\section{The Crack-up}

Shortage of baby formula in Hong Kong is not "scarcity" of biblical proportion that would have caught attention of Marx or Sartre. But this shortage is no fleeting circumstance. Something real and solid is emerging, not in the wake of, but being exposed by this shortage. That is, Hong Kong now appears as a "cracked-up plate", 9 to borrow the imagery in Fitzgerald's 1936 essay. This is more than a figure of speech. Hong Kong ominously shapes like a cracked-up plate consisting of the island of Hong Kong, Kowloon and the New Territories. The history of how the colony of Hong Kong came into being mirrored the process of how China was carved up by imperial powers in the hundred years from 1840s to 1940s.

As mentioned at the beginning of this Essay, the British took control of the island

8 Maureen Callahan, 'We should blow up the bridges' - coronavirus leads to class warfare in Hamptons, https://nypost.com/2020/03/19/we-should-blow-up-the-bridges-coronavirus-leads-toclass-warfare-in-hamptons/, March 19, 2020.

9 This author came up with this metaphor through reading William E. Connolly's bicameralism and comparing it with Deleuze's "double articulation". I was drawn to Connolly through reading Deleuze of course. Deleuze's thoughts on flight and intensity provide the overall vision of this Essay. Interestingly, I later found Deleuze used Fitzgerald's cracked-up plate to illustrate micropolitics. "But Fitzgerald says that there is another type of cracking, with an entirely different segmentarity. Instead of great breaks, these are microcracks, as in a dish." Gilles Deleuze \& Félix Guattari, A Thousand Plateaus: Capitalism and Schizophrenia, translated and foreword by Brian Massumi, (University of Minnesota Press, 1987), at 198. It is extremely gratifying to see this meeting of minds with such an intellectual giant as Deleuze. 
of Hong Kong under the Treaty of Nanking (1842) and then annexed Kowloon under the Treaty of Peking (1860). Both treaties were unequal treaties brought on by gunboats. Whether unequal treaties are void or voidable or void $a b$ initio is a very complex subject of international law that exceeds the scope of this Essay. Suffice to say, not all unequal treaties are in fact voided. Changing status quo is never easy.

The New Territories was a different story. By late 1890 s, almost $62 \%$ of China's foreign trade was with Britain. ${ }^{10}$ Britain was motivated to prevent other powers from dividing China into imperial possessions. ${ }^{11}$ In January 1898, the British government openly opposed to the alienation of any portion of Chinese territory. ${ }^{12}$ But Britain was not powerful enough to stop Russia, Germany, Japan from occupying parts of China. Against this background, the British government needed to wrap up its acquisition of the New Territories under something less than outright colonial occupation. While China was too weak to resist the British demand for this piece of land, it would be much more politically acceptable if the acquisition was executed under a 99-year lease. Both sides quickly reached agreement. China did not even demand any rental payment. ${ }^{13}$ The British considered the lease was merely a formality. Joseph Chamberlain, the Secretary of State for the Colonies stated that the New Territories should "be treated as an integral part of the colony." 14

At the time, it was a success for Britain to acquire this large piece of land without any costs or damage to its relationship with China and other powers. Over a century later, the fixed date of lease expiry sealed the fate of Hong Kong. The fault line was as geographic as it was historical in the making. Were it not for the undisputable lease, the British, though declining in its navy power, might have still attempted to preserve the status quo created by the unequal treaty of the colonial era. In the early 1980s, China, though very weak economically and militarily, had enough power, largely due to the geographic proximity, to take back Hong Kong with or without the pledge of no change of Hong Kong's way of life for 50 years. But China had no reason to do that, because China was opening up to the western world and embracing some elements of Hong Kong's way of life. Any non-negotiated recovery of Hong Kong would derail the economic reform that depended on accessing the western technology, market and capital. The British, despite being emboldened by the decisive victory against Argentine in the Falklands War in 1982, had no strength to keep Hong Kong unilaterally. The U. S. needed China in the strategic containment of the USSR. The fading imperialist pride of the British had no weight in American calculus. If Deng Xiaoping wanted to have Hong Kong back, the U. S. would not side with the U. K in resisting that recovery.

10 Steve Tsang, A Modern History of Hong Kong, (I. B. Tauris, 2007), at 37.

11 Id. at 37; Peter Wesley-Smith, Unequal Treaty 1898-1997, China, Great Britain and Hong

Kong's New Territories, (Oxford University Press, 1980), at 21-28.

12 Tsang, supra note 10, at 37; Wesley-Smith, supra note 11, at 42-43.

13 Wesley-Smith, supra note 11, at 40.

14 Tsang, supra note 10, at 40. 
Back in the years from 1942 when the British lost Hong Kong to Japan, to 1945, while the territorial composition was the same, the geopolitical calculus was different. Winston Churchill was determined to retake Hong Kong as a colony despite principled objections from President Roosevelt. "Hong Kong will be eliminated from the British Empire only over my dead body", insisted Churchill. ${ }^{15}$ Disregarding strong objections from Chiang Kai-shek's who was the Supreme Allied Commander in China theater to which Hong Kong belonged, President Truman acquiesced the British' military's retaking of Hong Kong. China, a victorious nation that had endured the long fight against the Japanese Imperialism ended up losing Hong Kong again to the British who was determined to restore its colonial possessions as much as it could. Much like 1989 was not "the end of history" as hyped by Francis Fukuyama, the Chinese people is amused by the idea that 1945 was the beginning of a liberal rule-based world order. It took a critical study of the British law for Peter Fitzpatrick to realize that "Racism was, in short, basic to the creation of liberalism and the identity of the European"; ${ }^{16}$ It took a painstaking empirical analysis of the evolution of immigration laws in six American nations for David Scott FitzGerald \& David Cook-Martin to claim the "elective affinity" between liberalism and racism. ${ }^{17}$ For the Chinese, they lived it.

"This battle was not fought for the sake of gaining positions or so many square miles of desert territory ... Let me, however, make this clear, in case there should be any mistake about it in any quarter: we mean to hold our own. I have not become the King's First Minister in order to preside over the liquidation of the British Empire ... As I have said, in this war we have no territorial aims. We desire no commercial favors, we wish to alter no sovereignty or frontier for our own benefit." Over and over again, in this renowned 1942 Mansion House speech, the defiant Churchill, while humbly naming himself "active ardent lieutenant" of President Roosevelt, kept a straight face in outlining his position on overseas territory. Churchill painstakingly enumerated a number of nations ranging from Egypt, Morocco, Algeria and Tunisia to Spain, Italy and restoration of Alsace-Lorraine to France. China was conspicuously omitted in his speech, despite that merely several months prior to the speech, Chinese Expedition Force under the Command of General Sun Li-jen and Regiment Commander Colonel Liu Fangwu fought a ferocious battle in Burma to save 7,000 British troops encircled by the Japanese army. ${ }^{18}$ It was hard for Churchill to swallow that the British force was in disarray in Burma. The fact that the rescue was made by an Asian country was an aberration that Churchill needed to filter out. It was only self-evident and rational to

15 Foreign Relations of the United States: Diplomatic Papers, 1945, Vol. 7, The Far East-China (Washington DC, 1969), 329-32, Cf. Kent Fedorowich, Decolonization Deferred? The Reestablishment of Colonial Rule in Hong Kong, 1942-1945, The Journal of Imperial and Commonwealth History, 28:3, 25-50, (2008), at 26.

16 Peter Fitzpatrick, Racism and the Innocence of Law, Journal of Law and Society, Vol. 14, No.

1, Critical Legal Studies (Spring, 1987), 119-132.

17 David Scott FitzGerald \& David Cook-Martin, Culling the masses: the democratic origins of racist immigration policy in the Americas, (Harvard University Press, 2014)

18 General Sun was awarded a medal by King George VI for his heroism and effective leadership. In 1992, the former British Prime Minister Margaret Thatcher met with Liu Fangwu and thanked him for saving the British army. 
Churchill that Hong Kong rightfully belonged to the Great Britain. Loss of Hong Kong to the Japanese was only an episode of "temporary disintegration of our empire". ${ }^{19}$

In the spirit of what Engels stated in his letter to Marx, Hong Kong people made the best out of the circumstances ${ }^{20}$ and was able to achieve per capita GDP not only higher than that in mainland China but also the Great Britain, a rare achievement for the colonized people. Lacking political freedom did not impede a vibrant market economy that had sustained spectacular growth since the 1950 s.

Milton Friedman was puzzled. In the 2002 preface to the fortieth anniversary edition of his classic Capitalism and Freedom, while triumphant in summarizing the shift of intellectual climate in favor of his thesis, Friedman was humbled by Hong Kong's experience. "After I finished the book, Hong Kong, before it was returned to China, persuaded me that while economic freedom is a necessary condition for civil and political freedom, political freedom, desirable though it may be, is not a necessary condition for economic and civil freedom. Along these lines, the one major defect in the book seems to me an inadequate treatment of the role of political freedom, which under some circumstances promotes economic and civic freedom, and under others, inhibits economic and civic freedom," said Friedman in concluding the Preface dated March 11, 2002. ${ }^{21}$ Friedman certainly had the first rate of intelligence alluded by Fitzgerald in his celebrated phrase "the test of a first-rate intelligence is the ability to hold two opposed ideas in the mind at the same time, and still retain the ability to function." Friedman was not daunted by the conflict in the dichotomy. He suggested that "if there is one major change I would make, it would be to replace the dichotomy of economic freedom and political freedom with the trichotomy of economic freedom, civil freedom, and political freedom." 22

Did Friedman concede too much and too soon? How would he have reacted to the eruption of discontent in Hong Kong in the summer of 2019? "After all, the dichotomy prevails!" Would he say that?

\section{The Oriental Pearl and the Flows}

What kind of economic and civic freedom has defined Hong Kong? "Keep dancing and horse racing", quipped Deng Xiaoping in pledging not to change Hong Kong's way of life. The British takes pride in the prosperity of Hong Kong. Compared with the colonial psychopathology as described by Frantz Fanon, the colonial life in Hong Kong seemed to be a match made in heaven: the British rule of law and the "apolitical"

19 Fedorowich, supra note 15, at 28.

20 "Men themselves make their history but in a given environment which conditions him." $C f$. Jean-Paul Sartre, Search for A Method, translated by Hazel E. Barnes, (Vintage Books, 1968) at 85.

21 Milton Friedman, Capitalism and Freedom, Fortieth Anniversary, (The University of Chicago Press, 2002), at ix

22 Ibid. ix. 
Chinese public who is obsessed with making money. The Oriental Pearl was no exaggeration. Hong Kong was not only the pride of the British empire, but also the envy of the mainland Chinese. The Chinese pop song "My 1997" became a hit in 1990. The singer Ms. Ai Jing was based in mainland China. The lyrics were written by a Hong Kong producer. "I am mostly in Guangzhou, as my boyfriend is in Hong Kong... he can come to see me but I cannot go to see him in Hong Kong... 1997, please come quickly so I can go to Hong Kong..." In the 1980s and 1990s, the indispensable entertainment on Chinese college campuses was watching Hong Kong movies on video in smelly and cramped classrooms on weekends. Hong Kong pop singers took the mainland by storm. "Glorious Years", in honor of Nelson Mandela: ${ }^{23}$

Dark skin gives him the meaning

of his life's devotion to the color struggle.

The years have changed possession into loss

The set of fatigued eyes still carries hope.

...

Can we make no boundaries between colors

On this earth, don't make distinctions between you and I

A riotous diffusion of colors emits beauty

Because there are no distinctions between each individual color.

This was one of many pop songs from Hong Kong in the 1980s and 1990s that have won the hearts and ears of two generations of Chinese in the mainland and beyond.

The dynamics of Hong Kong as evidenced by the flourishing arts and entertainment is beyond what the rule of law alone can offer. Flint, Michigan is under the rule of law no less. Western Virginia is under the rule of law no less. Neither is even remotely close to a pearl. To make a pearl, the flow of currents is needed. Literally, since the 1960s, Hong Kong has relied on water supply from the Shenzhen reservoir built on the East River, a branch of Pearl River (yes, the Pearl River was there long before Hong Kong earned the glamorous title of "Oriental Pearl" for her economic success!) on mainland at the below market price without being subject to any political conditions. ${ }^{24}$ Hong Kong has enjoyed 24-hour uninterrupted water supply since 1982. ${ }^{25}$ Figuratively, Hong Kong was at the place where multiple flows had their paths crossed, until the flows were interrupted or changed courses in recent years.

23 The song was by the renowned Beyond Band. The English translation of lyrics was by Han Keat Lim.

24 For a detailed account on how Hong Kong came to depend on the water supply from the mainland, see David Clayton, The Roots of Regionalism: Water Management in Postwar Hong Kong, in From a British to a Chinese Colony? Hong Kong before and after the 1997 Handover, edited by Gary Chi-hung Luk, China Research Monograph 75 Center for Chinese Studies, Institute of East Asian Studies, (University of California, Berkeley, 2017), 166-185.

25 https://www.wsd.gov.hk/en/core-businesses/water-resources/dongjiang-water/index.html 
Except for the years under the Japanese occupation, Hong Kong has always been a free port. Free flow of goods defined the identity Hong Kong early on. When the U. S. imposed embargo against mainland China in the 1950s, Hong Kong had no autonomy to ignore American wishes. Fortunately, the Hong Kong people found ways to make the flow of goods work despite the embargo. Hong Kong has become a center of international finance. Getting companies registered in Hong Kong and having business accounts opened take just a couple of days. That kind of efficiency was no longer possible when the U.S. began to seriously enforce anti-money laundering laws for drug enforcement and especially anti-terrorism purposes. Now it takes weeks if not months to get bank accounts opened in Hong Kong. Starting in 2018, Hong Kong company secretary became legally required to keep identities of key shareholders on file for inspection by the authority. This legal change was a direct result of pressure from the western countries led by the U. S. International business community now finds Delaware companies much more attractive as Delaware, a sovereign state under the U. S. federal system faces no external pressure to peep into the shareholder identities. ${ }^{26}$ Free flow of capital has always been promoted until it runs against other more important policy objectives many of which have nothing to do with needs or wishes of Hong Kong. Hong Kong was hit hard by the Asian Financial Crisis in 1997-1998 which triggered the worst recession in 40 years. ${ }^{27}$ Again in 2008, when the Great Financial Crisis hit America, the pain predictably transmitted to Hong Kong. Hong Kong's dollar is pegged to the U. S. dollar. In the 1970s, against the backdrop of Bretton Woods System's collapsing, Hong Kong authority decided to switch from Sterling to the U. S. Dollar to peg its currency. Hong Kong officially gives up monetary autonomy. The free flow of capital comes not only with expensive irritants such as enforcing draconian Anti Money Laundering laws at the behest of the U. S. Congress, but also inherent risks of economic destruction as evidenced in the two financial crises mentioned above.

It is an intriguing paradox that Hong Kong could handle waves of refugees and immigrants, legal or illegal, from the 1950 s to the early 1980 s, but had to resort to quota and license in reaction to the influx of baby formula shoppers. The economic growth in the years up to the 1980s were fueled by the drive of early generation refugees from mainland China and later generations of legal and illegal immigrants mostly from mainland China as well. But the migration pattern has changed in recent years. "The profile of the migrant population in Hong Kong has transformed from economic migrants in the years following the Second World War to welfare-dependent migrants today." 28 As singer Ai Jing was fantasizing going to Hong Kong for a more glamorous life in the early 1990s, Shenzhen, a backwater farming community to locate the reservoir to supply fresh water to Hong Kong in the early 1960s, was being developed into a mega city. Today, Shenzhen has a population of 20 million who produce drones,

26 Jana Kasperkevic, Forget Panama: it's easier to hide your money in the US than almost anywhere, https://www.theguardian.com/us-news/2016/apr/06/panama-papers-us-tax-havens-delaware 27 Y. C. Jao, The Asian Financial Crisis and the Ordeal of Hong Kong, (West Port: Greenwood Publishing Group, 2001), at 139-154.

28 Yue Chim Richard Wong, Hong Kong Land for Hong Kong People, (Hong Kong University Press, 2015), at 186. 
5G equipment, routers, electrical vehicles for customers worldwide. It is no coincident that Huawei, Tencent (the leading social media company) and DIJ (the leading manufacturer of drones) which threatened American technology superiority all started in Shenzhen as start-ups. Shoppers that make Hong Kong too much to bear are actually under very strict limitations imposed by the mainland authority. Americans may visit Hong Kong visa-free for up to 90 days. Tourists from mainland can only stay 7 days each trip. Each pass to Hong Kong is valid for two entries within one year. Were it not for those restrictions, there would have be even bigger flow of short term visitors generating more clashes sooner and on a wider range of issues. Meantime, Hong Kong residents may work and live in mainland China with almost no restrictions. In fact, many talented artists, business executives and investors have benefited hugely from the ever-growing economy in the mainland under the regulatory regime known as Closer Economic Partnership Arrangement (CEPA). Hong Kong's TV, movie and pop music industries have gradually run out of steam as mainland proves to be a much more lucrative market. "You know how long your study will take you? One day? No, one hour! We are nothing anymore", said a Hong Kong film industry insider to a researcher doing ethnographic fieldwork in $2005 .^{29}$

Hong Kong's economic and political system remains essentially unchanged. If there has been any fundamental change, it is to the better. Democratic governance made great strides since 1997. On November 25, 2019, notwithstanding a tumultuous summer, the district council election had a record turnout of 2.94 million voters, representing 71.2 per cent of registered electors, up from the previous figure of 47 per cent in $2015 .{ }^{30}$ This free exercise of democratic election was unthinkable in 150 years of the British rule. Democratic election as a formal process may carry all kinds of freight as mature democracies can testify to from their own experience.

What has changed significantly in Hong Kong is that the flows through this Oriental Pearl become much less dynamic. Hong Kong government and society has lived off financial sector and real estate sector for many decades without looking beyond the horizon. ${ }^{31}$ Their investment returns are calculated in terms of years but not

29 Sylvia J. Martin, The Death Narratives of Revitalization: Colonial Governance, China, and the Reconfiguration of the Hong Kong Film Industry, Critical Studies in Media Communication, Vol. 32, No. 5, 318-332, (December 2015)

30 Jeffie Lam, Sum Lok-kei and Ng Kang-chung, (25 Nov, 2019), https://www.scmp.com/news/hong-kong/politics/article/3039151/hong-kong-elections-tsunamidisaffection-washes-over-city

31 In the decade leading up to the 1997 Handover, the trend was already clear. Michael Taylor noted four major elements of Hong Kong's structural change in its economy: 1) the decline of manufacturing sector from $23.2 \%$ of GDP in 1984 to $8.7 \%$ in 1994 ; 2) the relative modest increase in importance of distributive trade; 3) the relatively large and still rising, proportion of GDP accounted for by "ownership of premises" and "rental services"; 4) The contemporaneous rise of the financial services and real estate industry, from 15\% of GDP in 1984 to $21 \%$ in 1994. Michael Taylor, Hong Kong's Economy and Its Global Connections: Prospects for 1997 and Beyond, in Hong Kong's Transition, 1842-1997, edited by Judith M. Brown \& Rosemary Foot, (Macmillan Press, 1997) at 168-172. The contribution of Financial, Insurance \& Real Estate to GDP reached $37 \%$ in 2007 . Ordinary Hong Kongers are turned into investors while real wage 
generations. They never made any serious investment in developing human capital towards high tech sector. ${ }^{32}$ While traditional manufacturing sectors gradually lost to mainland competitors, ${ }^{33}$ no advanced manufacturing capabilities have been developed in Hong Kong. Economic reliance on mainland visitors grew steadily. ${ }^{34}$ The freedom of international travel which is the envy of Chinese mainland residents did not bring in world class researchers in life science, material science, AI or telecommunications. In early 2000s, Hong Kong government intended to jump on the internet economy. ${ }^{35}$ Nothing came out of it. Taiwanese semi-conductor manufacturer SMIC planned to expand its presence in Hong Kong. Nothing came to fruition partly because of the de facto real estate hegemony in Hong Kong's political economy. Twenty years later, SMIC has a very successful presence in the Pudong New Area of Shanghai that continues to grow.

Hong Kong is of the international, by the international and for the international. 6\% of its judges are from foreign nations, ${ }^{36}$ unheard of in most jurisdictions. Lawyers, doctors and accountants typically have western educational credentials. Having second passports or residency rights in foreign countries is common among top earners. The income tax rate is $17 \%$ and Hong Kong residents' income outside of Hong Kong is not to be taxed by the Hong Kong authority. This mobility and freedom reflect a trade-off between time and space. The top class has or potentially has a life elsewhere (including the mainland), and time in Hong Kong is always a counting down. Hong Kong needs a quick return. Everyone and everything are in a hurry. Nothing is planned beyond a commercial mortgage life. Planning over generations is not capitalism. America does not plan beyond the next election and American working class could not afford saving for the future. But America has a vast and rich land to live off. American system rewards talents immigrating from other nations. For Hong Kong, investment in human capital is a waste of time. And time is money, of course.

growth is restrained. See Kim Ming Lee, Benny Ho Pong To and Kar Ming Yu, Financialization and Economic Inequality in Hong Kong: The Cost of the Finance-led Growth Regime, in Hong Kong 20 Years after the Handover: Emerging Social and Institutional Fractures after 1997, edited by Brian C. H. Fong \& Tai-Lok Lui, (Palgrave Macmillan, 2018), 127-151

32 Wei-Bin Zhang, Hong Kong: The Pearl Made of British Mastery and Chinese Docile Diligence, (New York: Nova Science Publisher, 2006), at 179.

33 “... by 1997, virtually the entire manufacturing sector of Hong Kong had been relocated to Guangdong Province. Between 1979 and 2001, Hong Kong invested US\$79 billion in the province and created an industrial hinterland that employed more than five million workers." Leo F. Goodstadt, Economic Relations between the Mainland and Hong Kong, an "Irreplaceable" Financial Center, in Gary Chi-hung Luk, supra note 24, at 198.

34 Stan Hok-Wui Wong, Real Estate Elite, Economic Development, and Political Conflicts in Postcolonial Hong Kong, China Review, Vol. 15, No. 1, (Spring 2015), 1-38, at 20 \& 21.

35 A Jump-Start In Cyberspace, Newsweek, International ed., (Apr 5, 1999) at 62.

36 Joyce Ng, Foreign judges must be retained in Hong Kong, former chief justice insists, https://www.scmp.com/news/hong-kong/politics/article/2096355/foreign-judges-must-be-retainedhong-kong-former-chief 


\section{Bumpkins \& Sardines}

"A member of the ground crew at an air base on the outskirts of London took a plane and, with no experience as a pilot, flew it across the Channel. He is colored; he is prevented from becoming a member of the flying personnel." 37 This was a story told by Jean-Paul Sartre in Search for a Method. This is also the true tragedy that happened in Seattle in our own time with recorded cockpit conversation between the control tower and Richard Russell, a 29-year-old man who stole the plane with no intention to land it safely. He intended to kill no one but he himself had no will to live on even he had the talent to fly the plane without any formal training. "Minimum wage, we'll chalk it up to that," Russell said on the flight radio to air traffic controllers. "Maybe that will grease some gears a little bit with the higher-ups." ${ }^{38}$ Russel apparently referred to the minimal wage of $\$ 15 /$ hour required by the city of SeaTac but not applicable to Airline employees such as himself. His impoverishment was "relative" or "subjective", as Sartre would say. Indeed, in Hong Kong where the legal minimum wage is under USD\$5 per hour, ${ }^{39}$ many people live in coffin-sized "apartments". Hong Kong, lauded as the best example of free economy by Milton Friedman did not introduce legal minimum wage until 2011. 40 "The down payment [for buying a flat] in 1991 was equal to 5 months of earnings; today [2015], it equals 80.9 months -15 times higher and almost out of reach for the average family." 41 "Astronomical prices continue to explore the furthest reaches of outer space, boldly going where no decent man has gone before and alienating an entire population of unfortunates who can only fantasise about owning that most basic of human comforts - a roof over one's head", ${ }^{42}$ lamented Yonden Lhatoo, the chief news editor at the most influential English newspaper in Hong Kong. The scarcity of land has always been a defining feature of Hong Kong. “... Scarcity is not a simple lack; in its most naked form it expresses a situation in society and contains already an effort to go beyond it." For reasons beyond the scope of this essay, Hong Kong has been unable to go beyond its despicable shortage of housing. As Lhatoo noted, Hong Kong has a fiscal reserve of HK\$2 trillion (about US\$257 billion), yet owning a home is out of reach for the vast majority of middle class. The young college graduates (those born of the 1980s), whose average salary in 2012 failed to surpass that of 1997, have neither prospect of affording down payments, nor qualifications for public rental housing. They are counterparts of Richard Russell who graduated from Washington State University in 2017 with a degree in social science yet struggling to make less than $\$ 15 / \mathrm{hr}$. "Their plight is compounded by the fact that their skill set is less valued in a labor market

37 Sartre, supra note 20, at 95.

38 David Gutman \& Hal Bernton, Richard Russell was a jokester who complained about work, but Sea-Tac plane heist still baffles friends, (August 20, 2018),

https://www.seattletimes.com/seattle-news/he-was-a-jokester-who-complained-about-his-job-butfriends-still-baffled-by-richard-russells-airplane-heist/

39 https://www.labour.gov.hk/eng/news/mwo.htm

40 Mathew Y. H. Wong, The Politics of the Minimum Wage in Hong Kong, Journal of Contemporary Asia, 44:4, (2014), 735-752

41 Yue Chim Richard Wong, supra note 28, at 215.

42 Yonden Lhatoo, Hopeless in Hong Kong: why the sordid state of housing can never be fixed in Asia's world city, South China Morning Post (online), (June 8, 2019). 
swamped by low-skilled service jobs."43 The government has been powerless to meet the basic needs in housing. But the Hong Kong people are proud and resilient. They always present themselves in a neat and professional manner. They respect and follow rules.

Understandably, the Hong Kong locals, in the same vein as those in the Hamptons, resent those busloads of tourists from mainland who shop non-stop, talk loudly or even eat noodles while riding in subway trains. They cross their paths as individual strangers. But day in and day out, the sentiment like "blowing up the bridge" becomes palpable as the unknown individuals from mainland becomes a collective. The election result in November 2019 was very much driven by identity politics. Shoppers from the mainland are perceived as country bumpkins who happened to have a few extra bucks for shopping. That is not something would tick good mannered Hong Kong locals off. They would hide their annoyances within themselves. But 40 million a year may be too many!

Over the span of two thousand years, Chinese peasants cut down trees in order to gain extra farm land. This was before any national coordination or socialist communes. Each peasant family or village did it on its own for its own benefit. But the result is deforestation that changed the landscape and ecology to the detriment of all Chinese peasants for generations. As Sartre put it, the destruction was more than the most determined enemy could possibly achieve.

Each shopper is no threat. Hundreds, thousands and tens of thousands, every day that is going to have consequence. Much like too many cars in the rush hour on Interstate 405 between Los Angeles and San Diego, they have the capacity to turn the 10-lane freeway into a huge parking lot, as the saying goes. The intensities matter and they can transform institutions. It is not clear whether the baby formula ration indicates the breaking point of the free trade or it is more of a populist reaction to the growing resentment towards mainland visitors. In either case, it is very telling. Hong Kong is too close to a prosperous major economy to be comfortable. Hong Kong cannot prosper without the flows, yet the flows even so tightly managed have proven to be so transforming. The autonomy of Hong Kong is a delusion.

\section{Textbook, Museum \& Identity}

"In Hong Kong to address the Asia Society this weekend, one of the things that strikes me again is that amid the profusion of colonial buildings in this teeming city, there is one starting absence. There is no museum to Hong Kong's colonial history", said Shashi Tharoor, Member of the Indian Parliament. Shashi reminded his audience that "It is curious that there is, neither in India nor in Britain or Hong Kong, any museum to the colonial experience." Shashi was not exactly correct. Hong Kong Museum of History does have a section on the colonial past. But Shashi got the larger 
point right in that how to present the colonial past to the Hong Kong people has been a touchy subject, to say the least. Among eight galleries devoted to The Hong Kong Story, The Opium Wars and the Cession of Hong Kong occupies Gallery 5. Critics challenged why the Japanese Occupation lasting only four years takes up the entire Gallery 7, while 150 years of British administration is reduced to "a few small and fragmented segments in Gallery 6 under the rubric "Birth and Early Growth of the City". ${ }^{4}$

During the British rule, the history of Opium Wars was avoided in the history curriculum. ${ }^{45}$ This is hardly surprising as we read "From the $26^{\text {th }}$ January, 1788, Australian History begins" in a 1923 Australian textbook; ${ }^{46}$ or, we heard President Regan told his audience in Shanghai in 1984 "we inherited a vast land of endless skies, tall mountains, rich fields, and open prairies..." The legendary "apolitical" Chinese in Hong Kong did not come from nothing. "Amendments to the Education Ordinance 1948, the setting up of a Special Bureau, the tightening of syllabuses, selection of textbooks, and the institution of the certificate examination were measures to restrict state-centered nationalistic education and the spread of communism." 47 The British administration "until the 1980s had deliberately discouraged political activism, national consciousness, and the emergence of a political culture of participation, representation, and accountability." 48 In 1976, the term "colony" was removed from the syllabus of Economic and Public Affairs and the topic concerning relations between Britain and China was first introduced. ${ }^{49}$ No civic education was introduced until after the SinoBritish Joint Declaration was signed in 1984. A new subject, "Government and Public Affairs" was introduced in 1988 which stressed the concepts of western democracies and the study of political processes in China." 50 The Hong Kong authority, still under the British rule, lacking interest in democracy for 150 years, seemed to race against time to get their students ready for democracy in the post-1997 era.

Forming citizens takes more than formal indoctrination at school. Even if we just limit our attention on formal education, the question arises as to who are to educate the educators? This is not a human resources matter that can be resolved by training or certifications. As Sartre borrowed from Marx: "the educators must be educated; this

44 Kam-yee Law, The red line over European colonialism: comparison of the Macao museum and Hong Kong museum of history after their return to China, International Journal of Heritage Studies, 20:5, (2014), 534-555, at 538.

45 Wai-Chung Ho, Politics, Culture, and School Curriculum: The struggles in Hong Kong, Discourse: Studies in the Cultural Politics of Education, Vol. 28, No. 2, (June 2007), 139-157, at 143.

46 Id. at 143.

47 Tracy Chui-shan Lau, Thomas Kwan-choi Tse and Yan Wing Leung, Dynamics of Chinese nationalistic education in Hong Kong from 1945 to 2012, Oxford Review of Education, (2016), Vol. 42, No. 6, 677-691, at 681.

48 Ming K. Chan, Hong Kong: Colonial Legacy, Transformation, and Challenge, The Annals of the American Academy of Political and Social Science, Vol. 547, The Future of Hong Kong (Sep., 1996), 11-23, at 19.

49 Ho, supra note 45, at 145.

50 Id. at 145. 
meant education must be an enterprise." ${ }^{, 51}$ Sartre did not mean that education was a business. Rather, education is a human praxis, or in some circumstances a struggle. It reflects human agency that transcends or attempts to transcend the prevailing conditions. Struggle indeed, many teachers resisted curriculum changes. After the 1997 sovereignty transfer, Hong Kong government introduced patriotic or nationalistic education programs and history textbook changes. Some survey claims "not more than $5 \%$ of Hong Kong teachers understood issues concerning the political authority and legitimacy of China. Another survey in 1999 indicated that only half of 494 secondary teachers presented nationalistic education as the core of civic education." 52 Many teachers ignored or crammed into the last few weeks of term the study of more modern Chinese periods and topics. ${ }^{53}$ Such chaos, resistances, surveys, press coverage of surveys, and normalization of resistance through publicizing surveys constitute the enterprise that shapes Hong Kong's youth who has unfortunately suffered from this peculiar form of colonial psychopathology, albeit after the colonial rule formally ended before their school age.

Much like the European Union is said to be a "fair weather" project, the rise of localism and xenophobia in Hong Kong has a strong correlation with the overall declining economic conditions, especially for those on the harsher end of the bargain. The local identity is a false proposition, not because there is no local identity, rather the local identity is always a relative concept ${ }^{54}$ and in the case of Hong Kong, the local identity alone is never the raison d'être for autonomy, much less independence. In the context of American constitutional development, the "wrong" local identity may lead it away from a fuller democratic representation. As the U. S. Senator Tom Cotton claimed, the distinctive identity of Washington D. C., i.e. not a "well-rounded" working-class economy the way Wyoming is makes it not qualified for the Statehood under the U. S. Constitution. ${ }^{55}$ One does not need to agree with Tom Cotton's rejection of the Statehood for the D. C., but he did illuminate the simple-minded reliance on local identity as the cause for constitutional independence. The local identity must be understood in the very circumstance surrounding the locale. The distinctive identity of Hong Kong is indeed in danger, but for causes having little to do with democracy or freedom. The flags of democracy and freedom are abused to cover the freight for the attempt of secession co-opted by international hegemony.

51 Sartre, supra note 20 , at 87.

52 Ho, supra note 45, at 150.

53 Id. at 144.

54 As Sonia Kruks argued in the context of feminism, the logical terminus for the tendency to subdivide into "ever-shrinking identity groups would have to be not merely subjectivism but solipsism since no one person's set of experience is identical to another's. Sonia Kruks, Identity

Politics and Dialectical Reason: Beyond an Epistemology of Provenance, Hypatia, Vol. 10, No. 2 (Spring 1995)

$55 \mathrm{https}$ ://thehill.com/homenews/senate/504628-gop-senator-dc-would-not-be-well-roundedworking-class-state-like-wyoming 
Senator Rand Paul, a doctor by profession from Kentucky caused a controversy when it became known that he had recklessly comingled with fellow Senators and staffers for days while he was waiting for his Covid-19 test result. He was tested positive. Fortunately, no one got infected by him. But let's run a quick thought experiment. Assume a few Republic Senators got ill either directly or indirectly due to being in contact with Senator Paul. Although non-life threatening, they were unable to vote and lost a major legislative battle to their colleagues on the other side of the isle. Tracing the line of transmission of the invisible and unidentifiable virus would be of interest to doctors and epidemiologists. But for historians, they would call this a peculiar contingency that only happened once in one hundred years. For philosopher Deleuze, this is known as flight - an event taking place at the "molecular" level although leading to consequences pronounced at the "molar" level, here the party politics and a specific Congressional vote of major significance. It is a flight or escape because it is not always predictable or even observable at the molar level. Micropolitics is an example of flight at work. "... every politics is simultaneously a macropolitics and micropolitics ... There is a micropolitics of perception, affection, conversation, and so forth."56 The first TV commercial of Trump's reelection campaign released in April 2020 used an image of Joe Biden bowing to a Chinese man. It matters little that the Chinese man in the footage was actually Gary Locke, a distinguished ChineseAmerican who was a former Governor of the Washington State. The factual error was only recognizable at the molar level. The impact is realized by the sublimated resonance of the Chinese face alone. "From the viewpoint of micropolitics, a society is defined by its line of flight, which are molecular. There is always something that flows or flees, that escapes the binary organizations ... A molecular flow was escaping minuscule at first, then swelling, without, however, ceasing to be unassignable." ${ }^{57}$ Mitch McConnell, another Senator from Kentucky was able to use the Senate procedural maneuvers to block President Obama's nominee for the Supreme Court and eventually helped securing the seat for Brett M. Kavanaugh. A Senator from a small state depending on Federal hand-outs was able to achieve outsize political results with impact potentially lasting generations to come. What if Dr. Christine Ford was able to produce a stained "blue dress" to buttress her testimony on what happened four decades ago at the summer house party? That could have derailed the appointment of Kavanaugh as a Supreme Court Justice.

Flight is not always this kind of contingency or minor, unexpected, yet consequential event. Nor is flight always as physical and discrete as allegedly Thomas Jefferson's semen flowing into Sally Hemings' body under constitutional segregation, or Trump's manipulating the U. S. Postal Service to influence the 2020 presidential election as feared by Democrats. Flight may be hundreds of years in the making as Max Weber noted: "The Puritans wanted to be a person with a vocational calling; we must

56 Deleuze \& \& Félix Guattari, supra note 9, at 213.

57 Id. at 216. 
be. ... Today asceticism's spirit has fled from this [steel-hard] casing - whether with finality who knows?" 58 Flight may be the outflowing of gold despite the Spanish government took measures to accumulate them. ${ }^{59}$ Weber's "elective affinities", 60 which was a metaphor rooted in chemical affinities, would be much less ad hoc if he worked out this concept as flight. Micropolitics does not necessarily mean that a massive number of small donors mobilized by social media push obscure long-shot candidates to electoral success posing threat to the establishment. The violent and prolonged eruption in Hong Kong in 2019 and the populism leading to the Brexit are both results of micropolitics at work. Milton Friedman would have been stunned by Hong Kong protesters in 2019 given his position in 2002. Friedman works at the molar level and switched back and forth between dichotomy (economic vs. political freedom) or trichotomy (adding civic freedom). For Deleuze, “... the molar and the molecular are distinguished not by size, scale, or dimension but by the nature of the system of reference envisioned." 61

The concept of flight is rooted in a larger vision of metaphysics, which is beyond the scope of this Essay. Suffice it to say, flight may explain changes in a wide range of phenomenon without resorting to the concepts of dialectics and negation. For Deleuze, dialectic "never goes beyond the symptoms ... That is why in questions of change and development, it conceives of nothing deeper than an abstract permutation where the subject becomes predicate and the predicate, subject." 62 The long arc of that "permutation" as masterfully presented in Sartre's analysis of Chinese peasants' treecutting praxis and Spain's economic downturn in the wake of accumulating gold from America has an impressive heuristic value. But the more solid or grounded analysis lies in "far more subtle and subterranean differential mechanism" as opposed to "opposition" or "contradiction" at mere "appearance" level. ${ }^{63}$ Imagine Hong Kong never became a vibrant economy of 7 million people. Instead it became a major naval base that was strategically important to both the Britain and the United States. And the base could remain vital without the New Territories which was under a 99-year lease. That could have changed the bargaining process between Britain and China in 1979. In other words, a 99-year lease of a piece of land that became indispensable to Hong Kong as a viable economy dramatically limited the Britain's options. The flight was 90 years in the making. The weak became stronger, and the strong became weaker. The proximity between Hong Kong and mainland made embargo-evading - flight in almost literal sense-- possible during the cold war, which led to establishment of several business empires in Hong Kong. As the international relationship changed after Nixon's visit to

58 Max Weber, The Protestant Ethic and the Spirit of Capitalism, translated by and introduced by Stephen Kalberg, The Revised 1920 Edition, (New York: Oxford University Press, 2011) at 177. 59 Jean-Paul Sartre, Critique of Dialectical Reason, Volume One, translated by Alan SheridanSmith, (London \& New York: Verso, 2004) at 173.

60 Weber, supra note 58 , at 109.

61 Delezue \& Félix Guattari, supra note 9, at 217.

62 Gilles Deleuze, Nietzsche \& Philosophy, translated by Hugh Tomlinson, (New York: Columbia University Press, 1983), at 157.

63 Id. at 157. 
Beijing, the proximity also made massive legal trade with mainland possible and highly competitive. As the legend goes, forty years ago, the founder of SF Express, now a fastgrowing giant competing with FedEx, started his delivery business by personally carrying critical parts across Hong Kong and Shenzhen border to meet manufacturers' urgent needs. But that same proximity also makes unstoppable streams of shoppers from mainland a reality today. Each shopper from mainland, just like individual treecutting Chinese peasant over 2,000 years ago, is inconsequential. "There is no joint undertaking, but still the indefinite flight of particular undertakings inscribes itself in being as a joint result." 64 "Through molecular homogeneity, the multicity of actions is diffused in the 'community' of being ... there is just one seal impressed on just one land." That joint result, that "community of being" and the one "seal" are being felt in Hong Kong, the rust-belt in America and beyond.

As we see in Hampton locals' reaction to COVID fleeing Manhattanites, identity otherwise inchoate can be quickly solidified under challenging circumstances. "Just blow up the bridge!" is obviously a rhetoric not meant to incite real acts of violence. Let's assume this sentiment grew much stronger and on a wider basis. Further assume that Yao Ming, the NBA legend from China tweeted this heated message indicating his solidarity with the overwhelmed locals in Hampton. Was he within his First Amendment right to do this? Certainly. Was he sensible in doing this as a public figure but a foreigner? Was it reasonable for the Manhattanites to take offense? Probably. This hypothetical is meant to be an analogy to the Rockets' general manager Daryl Morey's tweeting "Fight for freedom. Stand with Hong Kong" to show his support to Hong Kong protesters. Probably unknown to Morey, the very phrase he tweeted was a code message for the Hong Kong separatists. The analogy is obviously not air tight for a number of reasons. First, the emotional and political charge in the Hampton situation is incomparable to that in the Hong Kong situation. "Just blow up the bridge" was clearly a rhetoric. But Hong Kong was literally on fire at the time. Second, from the perspective of Morey and his fellow Americans, their support for Hong Kong protesters is a much more principled position while the hypothetical Yao Ming's tweet was a merely frivolous and insensitive interruption into a heated family feud.

Indeed, American support for Hong Kong protesters is not limited to Morey. House Speaker Nancy Pelosi called the large demonstrations in Hong Kong "a beautiful sight to behold". ${ }^{65}$ In what sense was it beautiful to see a city on fire, literally? It takes a high level of abstraction to see beyond the smokes and debris to find beauty.

Abstraction is the opposite to flight. Nancy Pelosi has the privilege to see the world in abstraction while her own country and people actually suffer from flights on many fronts. In 2019 Hong Kong, was the violent unrest a beautiful march for democracy and

64 Sartre, supra note 59, at 163-164; see also Christopher Turner, The Return of Stolen Praxis: Counter-Finality in Sartre's Critique of Dialectical Reason, Sartre Studies International, Volume 20, Issue 1, (2014), 36-44.

65 Richard Cowan, U.S. House Speaker Pelosi backs bill aimed at protecting Hong Kong rights, June 19, 2019, https://www.reuters.com/article/us-hongkong-pelosi-idUSKCN1TK2BP 
freedom, or despair and desperation that found echoes in the Black Lives Matter movement months later? Was the desire for violent destructions for the sake of destruction a step towards democracy or outburst of feverish xenophobia like those in other countries and in worse times? Nancy and Morey should be excused for not knowing how micropolitics work in Hong Kong. But their privilege of seeing the world in their preferred abstraction must be challenged as the world, America included, has been long suffering from that epistemological privilege without accountability.

First and foremost, it is the Chinese people that is glaringly absent in the abstract view projected by Morey \& Nancy. They see China, the State without the people, as the opposite of freedom and democracy. They claim to fight for freedom at home and abroad, but they do not bother to listen to the people. They promote democracy, but they do not give a damn about what the people wants. The free press, the academics and the politicians, in seamless collaboration, have long been cooking the so-called "China's Human Rights Record". This is a mysterious ledger that shows only deficit. This eternal deficit comes handy to hide and offset the undeniable decay in American governance. "The strong man can oppose the weak, not his own becoming-weak, which is bound to him by a subtle attraction", said Deleuze in interpreting Nietzsche. ${ }^{66}$ And there has been no audit as there has never been genuine interest in the human side of either China or elsewhere. The "record" is meant to be beyond audit.

You do not have to look into women's wombs just because someone loudly proclaims "pro-life". One should simply review how those pro-lifers react to life elsewhere to see their real motivation lies in God or the next life, rather than life in this world. In the same vein, the discourse of "human rights record" is designed to be a oneway projecting. The very mentioning of "China's Human Rights Record" has become a ritual in any conversation about China. The point is delivered as soon as this magic phrase is uttered. This phrase is the trump card or a wink with the guaranteed effect of closing the route to a meaningful discussion on either "human", "rights" or "China". This is the kind of enterprise that Sartre referred to. The very empty words of Democracy, Freedom and Free Press have become a cue, a whistle or an "interpellation" to toe the line. The line is of course at the "molar" level, to use Deleuze's word. "It is very easy to be antifascist on the molar level, and not even see the fascist inside you, the fascist you yourself sustain and nourish and cherish with molecules both personal and collective." 67

\section{Bad Faith}

China frustrates Morey, Nancy, Pompeo \& Co., at the molar level, of course. Instead of taking a closer look at the molecular level, they took the intellectually lazy way out. That is, they double down on their misguided abstraction. Their God-blessed ignorance is not to be dislodged by empirical counterpoints. They are the masters of

66 Deleuze, supra note 62, at 167.

67 Gilles Deleuze \& Félix Guattari, supra note 9, at 215. 
"politics of unknowing" empowered by the epistemology that condones "an imaginary of Other as terra nullius in their putatively mysterious lack of reason or truth."68 They act on the domino theory, the white plastic bottle touted by Collin Powell in the UN (Feb $5^{\text {th }}$ 2003) and the toxic mortgage debt instruments rated AAA with impunity. The U. S. failed to heed five Covid-19 related papers based on data from Wuhan published by the preeminent medical journal Lancet as early as in January $2020,{ }^{69}$ yet the Trump administration had the chutzpah to instruct its intelligence agencies to "investigate", namely cook evidence on the bogus claim of Covid-19's coming from the Chinese labs. Instead of calling out this "Birther" lies directly, the mainstream press, putting on a straight face, went along with reporting, which certainly had impact by way of sublimated resonance. And that resonance will be reflected in the Pew opinion survey on growing anti-China sentiment, which will be again reported by the press. The press reports further embolden the politicians to generate a new round of baseless hate mongering. What an enterprise! What a fraud! If this means overdraft on the credibility of America, so be it. The record of American democratic governance like its Federal budget has been running deficit for decades anyway. Overdraft is the way to go. Or as the Chinese saying goes, a son lives off his grandpa's estate!

Top tier American op-ed pieces cerebrally speculated Wuhan could be on the way to a revolution when people in Wuhan was in the worst public health crisis. They truly enjoy thinking and talking in grand narratives. In advocating "decentralized power" to fight the coronavirus pandemic that had already taken over 100,000 American lives, Senator Rand Paul had more faith in Friedrich Hayek than in Dr. Anthony Fauci. ${ }^{70}$ As Emily Rauhala, a reporter with the Washington Post tweeted on March 25th 2020, "One of the painful lessons of this crisis is the extent to which America cannot or will not identify with the Chinese pain. Every horror that is happening here happened first in Wuhan. We covered it. Many people did not care." Indeed, pain and suffering are too personal, too human and too detailed. Nancy and the Wall Street Journal types prefer the molar concepts of democracy and freedom, because they have a role to play, and play they did.

Speaker Nancy Pelosi's "beautiful sight" speech was more than pompous oratory as she noted that legislations relating to Hong Kong would be introduced. In November 2019, President Trump signed into law S. 1838, the "Hong Kong Human Rights and Democracy Act of 2019" (the "Act"). Reaffirming and amending the United StatesHong Kong Policy Act of 1992, the Act specifies United States policy towards Hong Kong, and directs assessment of the political developments in Hong Kong. In reality,

68 Lorraine Code, The Power of Ignorance, Philosophical Papers, Vol. 33, No. 3 (Nov. 2004), 291-308, at 302 .

69 See transcript of interview of Richard Horton, Editor-in-Chief of Lancet by Christiane Amanpour on PBS on April 27, 2020. https://www.pbs.org/wnet/amanpour-andcompany/video/what-uk-got-wrong-covid-19-dvetqd-2/

70 Dana Milbank, Could America's pandemic response be any more medieval? https://www.washingtonpost.com/opinions/2020/06/30/could-americas-pandemic-response-beany-more-medieval/ 
this law has nothing to do human rights or economic prosperity in Hong Kong, because if the U. S. reduces or removes the "preferred" treatment in the realm of trade and economics towards Hong Kong, it will only expedite Hong Kong's decline. In response to the "Law of the People's Republic of China on Safeguarding National Security in the Hong Kong Special Administrative Region" enacted by China which criminalizes "secession," "subversion," "terrorism," and "sedition", which was indisputably authorized by the Basic Law of Hong Kong, ${ }^{71}$ the U. S. quickly enacted "The Hong Kong Autonomy Act", which imposed visa sanctions on Chinese officials at the ironic moment when the EU blocked Americans' entry over the concern of high infection rate of Covid-19. The U. S. law has the impact of isolating Hong Kong in the name of preserving Hong Kong's autonomy from mainland China. Hong Kong must have stolen American heart, or how could one explain the quick and nearly unanimous action by the U. S. Congress in passing Hong Kong legislation while it is mostly paralyzed on many other urgent domestic issues?

The U. S. Congress's role playing has become a consummate art in itself. In purported defending human rights abroad, they were like "the attentive pupil who wishes to be attentive, his eyes riveted on the teacher, his ears wide open, so exhausts himself in playing the attentive role that he ends up by no longer hearing anything." This is an example by Sartre in describing what "bad faith" is. Bad faith is not to be equated with lying or cynicism. Lier knows he is speaking something inconsistent with the truth he knows. "Bad faith is possible only because sincerity is conscious of missing its goal inevitably, due to its very nature."72

Sartre's waiter in a café is playing at being a waiter in a café. In that playing, he is amusing himself. His customers demand the playing as a ceremony. He plays with his condition in order to realize it. Man is fearful of escaping what he is. It is an understatement to say that American politicians resort to grandstanding on human rights and democracy. There is much deeper anxiety in it. "The Jew is attacked in his religious identity, his history, his race, and his relations with his ancestors and descendants; every time a Jew is sterilized, the blood line is cut; every time a Jew is persecuted, it is the whole race that is persecuted through him. But the black man is attacked in his corporeality. It is his tangible personality that is lynched." ${ }^{, 73}$ China rises to become a

71 Article 23 of the Basic Law provides that "The Hong Kong Special Administrative Region shall enact laws on its own to prohibit any act of treason, secession, sedition, subversion against the Central People's Government, or theft of state secrets, to prohibit foreign political organizations or bodies from conducting political activities in the Region, and to prohibit political organizations or bodies of the Region from establishing ties with foreign political organizations or bodies." Hong Kong legislature has failed to enact such laws in 23 years after returning to China's rule. The national statute was promulgated after the continued unrest partly fueled by foreign powers' blatant meddling. This promulgation was expressly authorized by Article 18 of the Basic Law.

72 Jean-Paul Sartre, Being and Nothingness: A Phenomenological Essay on Ontology, translated and with an introduction by Hazel E. Barnes, (New York: Washington Square Press, 1992) at 111. 73 Frantz Fanon, Black Skin, White Masks, translated from the French by Richard Philcox, (New York: Grove Press, 2008), at 141-142. 
new target of attack based on race and ideology. As John Quincy Adams feared, the U. S. goes abroad in search of monsters to destroy. In early May of 2019, Dr. Kiron Skinner, then Director of Policy Planning at the State Department described the conflict with China as a "fight with a different civilization." A black woman notwithstanding, Dr. Skinner said, "It's the first time that we will have a great power competitor that is not Caucasian."74 Formerly a scholar at the Hoover Institute at Stanford, Dr. Skinner is indeed a properly trained scholar/official. A misspoken fact by someone who has completed her identity flight proves more than tons of correct statements could do. This is not the first time that someone of intellectual authority loses basic judgment when things come to China. On the eve of Hong Kong's return to China, Milton Friedman predicted that the Hong Kong dollar will not survive the colony's return to Chinese control. Friedman suggested that after 1997 Beijing would covet the $\$ 43$ billion in foreign reserves - mostly US dollars - accumulated by the Hong Kong Monetary Authority. Calling the temptation to eliminate the Hong Kong dollar enormous, Friedman predicted it would not last for more than 2 years beyond $1997 .{ }^{75}$ The reality is that in 2004, Larry Summers sounded a different alarm that China's surging foreign reserve to the tune of 440 billion would pose a "terror of financial balance" to the United States. Four years later, the financial terror did come by way of the Great Financial Crisis, not from China but from the U. S., the center of the liberal rule-based world financial order.

Churchill and his intellectual descendants kept finding history escaped them. This is "not because they did not make it; it is because the other is making it as well", said Sartre. ${ }^{76}$ In reaction to Morey's tweet in support of a message that is a coded language for the "radical, still-small, surely futile movement for Hong Kong independence", ${ }^{77}$ which has neither basis in international law nor groundings in reality, millions of Chinese fans expressed their outrage and threatened to boycott broadcasting of NBA games. NBA suffered a huge financial loss as the TV broadcast was suspended in China. This was shocking to the editorial board of the Wall Street Journal because weaponizing consumers and access to the financial system used to be American monopoly. The vast majority of American opinion leaders, true to their "deliberately educated ignorance of white schools"78 rushed to Morey's defense on the ground of freedom of speech. Few like Stephen Smith, a sports radio show host on ESPN had the basic decency and common sense to see the merit of Morey's controversy - it is not about Morey's freedom of speech, it is about whether he has even a basic respect of others, namely the

74 Joel Gehrke, State Department preparing for clash of civilizations with China, https://www.washingtonexaminer.com/policy/defense-national-security/state-departmentpreparing-for-clash-of-civilizations-with-china

75 Nigel Holloway, Far Eastern Economic Review, Volume: 158, Issue: 8 at 55, (01/01/1995); For a more detailed account of reality that rejected false predictions by Friedman and other lesser but still very influential American economists on Beijing's intention to Hong Kong's finance, see Y. C. Jao supra note 27, at 171-181.

76 Sartre, supra note 20 , at 88.

77 Jacques deLisle, Hong Kong's Summer of Discontent: Another Battle in the Long War over Autonomy, Democracy, and the Rule of Law, Orbis, Vol. 63, Issue 4, (2019), 473-504, at 484. 78 W. E. B. Du Bois, Dark Water: Voices from within the Veil, (2019), at 26. 
millions of Chinese consumers from which NBA made millions of dollars.

From the unrest in Hong Kong to the NBA incident, to Covid-19, again and again, this ruling cadre in America makes fact-trashing a way of living. But they do abide by journalistic rules. They check two sources diligently. They quote each other "scholarly" exactly Edward Said noted in analyzing the discursive formation of Orientalism in the previous centuries. ${ }^{79}$ But all these methodical efforts take place within one narrow frame of mind. They celebrate violent storming of the legislature building in Hong Kong, but denounce Yellow Vests as violent law breakers. They pretend to see no connection from Yellow Vests to Hong Kong and Portland. If they fall over themselves for Hong Kong's failure in achieving "universal suffrage" in less than three decades after returning to China's rule, ${ }^{80}$ why would they leave 3 million residents of Puerto Rico, a population larger than 20 states in the U. S., "in limbo in which they have neither meaningful Congressional representation nor the ability to self-govern themselves." 11 The fact that Puerto Rico's lacking democratic representation after 120 years under American rule hardly makes news in American media. While the Trump administration, the Congress and the leading American papers got excited over the Hong Kong's "losing freedom" in the wake of the National Security Law imposed by Beijing, essentially no attention was paid to the U. S.' rejection of funding for the Puerto Rico Plebiscite scheduled for November $3^{\text {rd }} 2020$. It exceeds the scope of this essay to present the farcical legalese of the U. S. Department of Justice's letter decision dated July 29, $2020 .^{82}$ Suffice it to note that this sort of rejection had happened in 2012 and 2017 in recent memory. The U. S., in the name of letting the people of Puerto Rico to determine its political status, has in fact made them jump legal hoops all these decades with no legally binding plebiscite ever allowed. The free press freely bickers over trivial stuff and freely conspires to make a narrow framework into the mainstream. Ignoring flights that erode the "city upon a hill", this "gang of elite" 83 misappropriates their forefathers"

79 Edward W. Said, Orientalism, at 23 (Vintage Books, New York) (25th Anniversary Edition, 2003.)

80 The concept of "universal suffrage" appears in the Basic Law of Hong Kong which understandably provides no specific definition. Universal suffrage under the Basic Law does not even necessarily mean one person one vote. Rather, "universal suffrage" is expressly provided only as a political vision in the future after "an orderly and gradual process" of reform. The ideal of universal suffrage in Hong Kong is meant to make the nomination of the Chief Executive and election of legislators to be more broadly based than the current process. That the U. S. positions itself as an authority demanding an immediate conversion into "universal suffrage" in Hong Kong is as comic as a foreign power's demanding the U. S. to lead by example: to replace its two-party system and the electoral college with a one-person-one-vote direct democracy.

81 "In the light of recent Supreme Court jurisprudence and Congress's adoption of the Puerto Rico Oversight, Management, and Economic Stability Act there seems to be good reason for the Special Political and Decolonization Committee of the United Nations to conclude that the island is no longer a self-governing territory." Report of the Special Rapporteur on extreme poverty and human rights on his mission to the United States of America, (May 4, 2018), at 8.

(https://digitallibrary.un.org/record/1629536)

82 https://www.elnuevodia.com/corresponsalias/washington-dc/notas/el-departamento-dejusticia-de-estados-unidos-descarto-validar-el-referendum-estadidad-si-o-no/

83 Jean-Paul Sartre, Preface, in Frantz Fanon, The Wretched of the Earth, translated from the French by Richard Philcox, (New York: Grove Press, 2004), at lix. 
legacy at the expense of American people. The decadence of America in physical infrastructure, institutional competency and moral integrity is laid bare in the ongoing Covid-19 crisis. Yet the grandiose Churchillian deception continued. Hannity and Carlson Tucker's ratings topped the chart in late April 2020. President Trump, by way of an executive order, promised a new national park of statutes before a crowd wearing no masks in the shadow of Mount Rushmore on July $4^{\text {th }}$.

It is beyond the scope of this Essay to unmask the entire American enterprise that hysterically weaponizes a self-referential machine of abstraction to continue the dominance abroad and cruelty at home. In the case of Hong Kong, what must be unequivocally rejected is the sinister attempt to use Hong Kong to deliver "hard ons" for those who increasingly cannot get high elsewhere. Hong Kong is an economy that has nearly exhausted itself in the run of unfettered capitalism to the cheers of Milton Friedman. A well-paid "impresario of China trade" now realized that the "talents" (mainland, Taiwan and the U. S.) under its management for the last several decades all have their own trajectories beyond the reach of Hong Kong. ${ }^{84}$ It is belatedly yet predictably suffering from an identity crisis in the wake of the colonial rule. The nascent democratic process is in the danger of being abused for self-destruction purposes. The delusional aspiration for "autonomy" of Hong Kong fueled by those politicians, young and old, who are neither "ethical, responsible nor having any sense of proportionality" is sending a generation of young Hong Kongers off the cliff, much like the pro-lifers in the State of Louisiana, in the name of life, enacted the infamous "Act 620" under which doctors performing abortion procedures would be required to have admitting privileges at a hospital within 30 miles. In reality, not only does a pregnant woman in Louisiana fare worse than pregnant women in developed countries around the world, Louisiana's maternal mortality rate (58.1 maternal deaths per 100,000 births) is on par with that of countries with current or recent military conflicts, such as Syria (54.1), Iraq (58.6), and Kyrgyzstan (47.8). ${ }^{85}$ Once a pearl, Hong Kong is now used by American politicians as another stone to fortify their hold of "learned orthodox" (Whitehead) which suppresses different others at all costs. Yet, the crack-up of Hong Kong, the fault line left in the wake of the Brexit and the decay beneath the City upon a hill share the same lines of flight that are becoming more visible every day.

First draft, New York City, 05/06/2020

Revised, Shanghai, 09/07/2020

Sh3949@columbia.edu

84 Taylor, supra note 31, at 173.

85 Priscilla J. Smith, Brief Of Amicus Curiae Information Society Project At Yale Law School In Support Of Petitioners Seeking Reversal, June Medical Services L.L.C., ET AL., Petitioners, vs. Rebekah Gee, Secretary, Louisiana Department Of Health And Hospitals, Respondent. 